\title{
Maritime Potencies in Quranic Perspective and the Role of Indonesian Youth
}

\author{
Serli Roisca \\ Institut Agama Islam Negeri Curup \\ roisca.serli@gmail.com
}

\begin{abstract}
Drawing the concept of the sea through the perspective of the Qur'an needs to be done, so that people know how to manage, explore, and utilize the sea. Therefore, for the purposes of exploration is required exploratory methods are balanced and proportional to avoid the occurrence of sea damage and its contents. Positioning sea exploration as one a common platform in the economic development of Indonesia, it seems that it is not only a feasible solution for the Indonesian people to rise from the crisis. Thus, they will gain prosperity and happiness in their lives. Islamic Idealism requires that the issue be restored and resolved based on the teachings contained in the Qur'an and Sunnah. So, the Qur'an serves as a guide for life and human life has been very clear exposes the potential of marine. Alqur'an has clearly exposed so potential mankind in the utilization of natural resources, especially marine resources. Young Indonesians proclaimed to be demographic bonuses in 2020 are the nation's assets and future generations that must be able to maintain the work ethic of the sea as the embodiment of maritime culture that is still attached. The working ethos of the sea should be ingrained in the life of the youth as the generation of the nation so that the next 50 to 100 years of progress will remain intact. Therefore, improving the quality of youth especially with regard to the utilization of marine potential is very important to be done through maritime culture as a nation culture that should always be invested as the main pillar of youth development of Indonesia.
\end{abstract}

Keywords: sea, maritime, Al-Qur'an.

\section{Introduction}

The ocean is one part of the earth. As a Caliph,a humanhas an obligation to manage the region in order to take advantage of it. In another hand, sea as agift of Allah is obliged to be preserved for the next generation which is also entitled to this gift. Remembering the fact that the surface of the planet earth which width is estimated to reach 510 million square kilometers, nearly two-thirds of the parts (70\%) consists of the region lake.Only $1 / 3$ part only which is the mainland. Now marine

AJIS : Academic Journal of Islamic Studies vol. 3, no. 1, 2018

IAIN Curup - Bengkulu | p-ISSN 2580-3174, e-ISSN 2580-3190

Available online: http://journal.staincurup.ac.id/index.php/AJIS 
Indonesia itself, consists of more than $3 / 4$ area of the national connect between one island with other islands.

Indonesia is known as the largest archipelagic country in the world with a number of the island more than 17,000.amount indicates also the wealth of biodiversity that belongs to Indonesia. In the book issued by the Conservation International: "Megadiversity : Earth's Biologically Wealthiest Nations" (1998) mentioned that Indonesia is in the second sequence in the case of biodiversity. But eksplioitasi excessive force on biodiversity resources is now become critical issues and become the problem of the management of biodiversiti.last issue many attracted attention is the coral reefs because of the central role in marine ecosystems.View the condition of the region of Indonesia that is so worrying, then it is only fair when Indonesia began to rebuild the maritime culture in order to optimization of the sustainability and the potential for marine affairs.

The sea on the side as a cheap means of transportation, also save a lot of natural resources that can be explored, among others various sources of building materials such as sand, gravel, glass; source of minerals such as manganese, cobalts, mud minerals, phosphorites; food resources such as fish and various sea plant; source of chemicals such as sodium and potassium; source of energy from the waves and conversion of the heat energy. Beside of that,sea alsoas the oil resources of the earth the abundance of extremes and as a means of recreation and health.so many potential marine that we can take the advantage of the one through the culture of maritime to always prepare and explore the wealth of the sea.

However, the maritime culture of the Indonesian nation is still apprehensive. The maritime culture of the Indonesian nation has not yet grown, not only in the community but also at the level of the wisdom maker. What is now is the fact that in the last few decades Indonesia's marine potential has been dumped. poor fishermen scavenging fish in the ocean with torn nets here and there. While foreign ships with all sophistication of fishing technology and free fish processing milling about tons of fish in Nusantara. So waters, Indonesia has not been able to take advantage of marine as a source of welfare. It is very unfortunate with the wealth of Indonesian society should be a rich society. But in fact, there are still many Indonesian people who are below the poverty line. 
Talking about the business of maritime culture rooted in the whole generation of people, hence the need for an effort to increase maritime resources that are reliable and professional. Given that the utilization of the sea primarily as a source of food has not been optimal due to the quality of labor factors in the exploitation and cultivation of the sea is still lacking. Then attempt to optimize the role of youth in this regard is through youth empowerment program through a social approach to maritime culture.In addition, one of the obstacles to returning the maritime culture is the lack of understanding and attention to the next generation in the maritime field.This happens because the paradigm through the younger generations to work together to develop the potential of the ocean is still often overlooked. Therefore it needs a solution in the form of re-growing maritime culture of optimizing the preservation and utilization of marine potential by the nation's generation.

Stand on the mind on the excavations the concept of the sea through the perspective of the Quran needs to be done so that the community knows how should manage, explore, and take advantage of the sea. Therefore, for the purpose of exploration is required a balanced exploration method and proportionate to avoid damaging the sea with its contents. Fitting the exploration of the sea as one of the common platform in the economic development of Indonesia, it seems not only a feasible solution for the Indonesian people to rise from the crisis. So that that way they get welfare and happiness in his life. The idealism of Islam wants the question returned and completed based on the teachings contained in the Quran and the Sunnah. So, the holy function as a guideline for life and human life has been very clearly explained the potential of marine. The Qur'an has clearly explained so potential of mankind in the utilization of natural resources, especially marine resources.

Indonesian Youth that overdue mmenjadi demographic bonus on 2020 is an asset the nation and the next generation that must be able to maintain the work ethos sailing as a manifestation of culture bahari still attached. The work ethos sailing must mendarah flesh in the life of the young generation as a nation to 50 to 100 years to the front of the progressivity is still maintained. The improvement of the quality of young 
people especially regarding the utilization of marine potential is very important to be done through the maritime culture as the culture of the nation that must always be embedded as the main pillars of the development of Indonesian youth.

\section{Marine Potencies and Its Utilization in al-Qur'an}

In Islam, the marine potential has been clearly explained in the QS. An-Nahl verse 14:

And He it is Who has made the sea subject), in order that ye may eat thereof flesh fresh (fish), and bring forth from the sea ornaments to wear, and thou seest the ships sail through it, and that ye may seek profits from His bounty, and that ye may be grateful.

Allah Almighty warns that among His infinite favors for mankind, is subdued Ocean with all its contents so that people can eat fresh meat produced by its fish, wearing jewelry from what can be extracted from the base of various kinds of gems, in addition to the facilities which he gave to the place of the traffic of the ark and the ships that brought people and goods to reach places that could not be reached by land and the desert. ${ }^{1}$

This shows that the potential of marine resources for human survival. The sea with an area of $2 / 3$ of the territory of Indonesia should be a concern for the entire Indonesian nation to be utilized. The fact shows that Indonesian people tend to utilize the potential of land in fulfilling their life needs which resulted in overland exploitation. While the maritime culture to exploit the potential of marine resources has not been done optimally. So from that, it needs understanding from all parties to realize the maritime culture of Indonesia.

The utilization of marine potential according to Al-Qur'an, among others, as follows.

1. Sea as a place to live and residence, the earth is equipped with various facilities and facilities supporting human life. This is revealed by Allah SWT in His word of QS. Al-Baqarah: 29:

\footnotetext{
${ }^{1}$ Salim Bahreisy, 2005, Tafsir Ibnu Katsir Jilid 4, Surabaya: Bina Ilmu, p. 589
} 
He it is Who created for you all that is in the earth. Then turned He to the heaven, and fashioned it as seven heavens. And He is knower of all things.

This verse confirms the warning of Allah on the verse that Allah has bestowed great grace upon man, created the heavens and the earth for man, to be taken advantage of, so that man can keep his survival and that man should serve his Creator, God, to family and society. ${ }^{2}$ This shows that humans as earth's inhabitants should be able to utilize natural resources, especially marine resources as well. Optimizing the exploration of marine resources is what requires human intervention in managing it.

2. The sea contains very high levels of minerals and many benefits for human life, in the Qur'an many mentioned signs for human use of natural resources in the form of this sea, because the sea contains not only the salt but also can be used as a means of communication between trade purposes and so on.

3. As a source of protein from fresh fish and contains gems that can be benefited by mankind. Similarly, this has been described in the Qur'an. Al Maidah: 96

It islawful to you is the pursuit of the sea and the food of the sea as the delicious food for you and for those who travel; and forbidden is the pursuit of land, for you in the state of Ihram. and keep your duty to Allah in Whom ye will be gathered.

In this verse Allah explains that he justifies for the believers, those who wear ihram cloth, or not, to eat seafood, including rivers, lakes and so forth and which are obtained easily, such as the new fish dead and floating or fish are stranded on the beach and so on. All of it was granted by God as a delicious meal for them and for those who were on the way. Then Allah reaffirms that he forbids the believers from catching the land game, as long as they are wearing the ihram cloth. At the end of the verse, it is reminded of the believers that they always fear Allah to whom He will be gathered on the Day of Judgment, to be accountable for their

${ }^{2}$ Kementerian Agama RI, 2010, Al-Qur'an dan Tafsirnya Jilid I, Jakarta: Lentera Abadi, 
deeds and then to be rewarded with rewards or punishments that are in harmony with those deeds. ${ }^{3}$

4. The Ark in the oceanships in the ocean bring benefits to humans because they can move from one place to another as described in the QS. Al-Baqarah: 164:

In the creation of the heavens and the earth, and the alternation of the night and the day, and the ships that sail through the sea bring what is useful for mankind, and what Allah sends down from the sky in the form of water and with water that he turn on the earth after death (dry) him and he spread out the earth was all kinds of animals, and pengisaran wind and cloud that controlled between the heavens and the earth; indeed (there) signs and unity are Signs for people who reflect.

He created the heavens and the earth for human purposes, then the man should pay attention to and reflect on the grace of Allah the holy because of the attention to the contents of nature everything will grow assured him the oneness and His power, will expand knowledge of its on natural creation, knowledge that can utilized as desired by the All-Knowing God. ${ }^{4}$ In verse 164 of the letter of Al Baqarah, it is explained that the ships or the like which God has inspired to humans to make and sail with the help of the wind by carrying merchandise are by Allah's permission. It shows that the vast sea of Indonesia is very potential utilized in the development of the cruise industry in Indonesia.

5. Development of Science

As has been explained in the QS.al-Baqarah: 164 that the creation of the heavens and the earth, the alternation of night and day, and ships sailing in the oceans are not only beneficial to mankind but also the teaching of the intelligent. It is said to be a teaching for them, because the intelligent people always read, examine, and explore the characteristics of something. They read nature, signs of the times, history, and self, whether written or not. the sensible

\footnotetext{
${ }^{3}$ Kementerian Agama RI, 2010, Al-Qur'an dan Tafsirnya Jilid III, Jakarta: Lentera Abadi, p. 25

${ }^{4}$ Kementerian Agama RI Jilid I, Op.Cit, p. 240
} 
always read and repeat in nature's reading until it reaches the maximum limit-then they not only acquire the ability to read but also generate new knowledge and insights to which they then develop.

Likewise, the word al-fulk in this verse means the boat or boat. To make boats requires knowledge of the nature of water, wind movement, air, clouds associated with seasons, basic principles of fluid physics as well as other basic laws such as Archimedes law for floating objects, or design and construction concepts. Finally, humans can make ships or boats to sail across the ocean so that they can explore the corners of the earth. In this alternation of night and day, there is a hint of time and direction because these two things are needed in the voyage. From this natural phenomenon also humans create science falaq and knowledge of the useless weather fulfills many human needs. ${ }^{5}$

Thus one of the potential utilization of marine, namely by doing the development of science, especially in the field of marine. Development of this science of course after done and undertaken the process of various scientific activities; through observation and research on oceans. This development is not only in line with the Quranic commands, but also supports the improvement and advancement of the fishery sector in particular and other sectors within the scope of marine. It is also hoped that by increasing the income from the fishery sector, the fishermen-a community directly involved in the marine sector-can elevated economic status to a better state, regardless of the poverty experienced so far. This is the ideal goal that is expected for the universe created by God for human beings can be utilized well for the sake of his welfare.

\section{Empowerment of Youth's Role in Improving the Maritime culture in Indonesia}

Portrait of young Indonesians who have a strategic position as the heir to the future of the nation. Based on the projection of the Central Bureau of Statistics (BPS), in 2015 the number of youth reached 62.4 million people. That means, the average number of youth $25 \%$ of the proportion of the population of Indonesia as a whole. Therefore, the

\footnotetext{
5Kementerian Agama RI Jilid I, Op.Cit, p.241-242
} 
strategy against youth development has an important and very strategic. Likewise the important role of youth in improving economic development by increasing knowledge about maritime. Understanding of Indonesia marine potential is very important given to the entire generation of the nation in order to foster a maritime culture that is the optimization of the conservation and utilization of the potential of the sea in Indonesia.

Demographic Bonus, based on BPS projection mentioned above, in the range of 2010-2030 Indonesia is also projected to get 'demographic dividends' (demographic dividend). In demographic terms, it is called a window of opportunity. In the period of 2020-2030, the working age population (15-64 years) will reach $70 \%$. The remaining $30 \%$ are unproductive people (under 15 years and over 65 years old). Judging from the number, the productive age population reaches 180 million and the unproductive population is only 60 million people. Therefore, improving the quality of youth especially with regard to the utilization of marine potential is very important to do. Given the importance of the existence of youth in the community. In fact, Allah also gives special talks on youths enshrined in Surat al-Kahf [18]: 13:

Means: "We tell you (Muhammad) this story correctly. Surely they are youths who believe in their Lord, and We also add to the guidance. "

It contains a hint that youth are the elite group in society that always creates great, shocking and shocking news. The youth are the ones who always make sensations and breakthroughs and stirring changes. In fact, the youth are the groups that are always feared by the as well as in the exploration of marine potential, youth is a State asset that plays an important role in managing marine potential. The first step in empowering Indonesian youth as a demographic bonus is to analyze solutions by studying the problems faced by youth first.

In addition, the statistics of the world's Islamic population show that Indonesian Muslims occupy the top ranking. Muslim Indonesia is a collection of Muslims who gathered in one place in the universe. In quantity, Indonesian Muslims reach up to more than 190 million people who constitute $87 \%$ of the largest population of the archipelago on earth. Uniquely, the place where most Muslims live in the largest archipelago on earth. Masha Allah. The maritime tradition of the Indonesian nation has 
also been ingrained and long-lived. This is evidenced by some historical records, artifacts, historical relics and language and cultural traces of the nation that spread from Madagascar in the Indian Ocean to Hawaii and Marquesas in the Pacific Ocean. ${ }^{6}$ It shows that the Indonesian nation has a big contribution to the utilization of marine potential in Indonesia. Therefore, it needs optimization of the role of youth in rooting maritime culture from an early age. This matter In the context of Indonesia, there are three main problems faced by youth are as the following.

Firstly, the quality and capacity of youth are still low. This is indicated by the participation of schools and the level of youth education in Indonesia. Based on BPS reports in 2012, 81.15\% of youth are out of school and generally employed, looking for work, housewives and unemployed and $17.48 \%$ are still in school at various levels of $6.46 \%$ Higher Education, the rest $39.96 \%$ of high school graduates, $32.03 \%$ of junior high school graduates and the rest are elementary school graduates and do not have a diploma or no school.Solutions offered: Improving the quality of education of Indonesian society, especially fishermen. In this case, the context is the fisherman as the head of the household, and the fisherman as a family set. The least illiterate fisherman can read or pass in package A or B. The fisherman is expected to complete secondary education. So that the future access to technology development of marine, economic improvement is easier to do.

Secondly, life skill and life skills of youth are still very low. This is indicated by youth unemployment rate in Indonesia based on BPS data for 2012 is $8.32 \%$ and the rest work and are looking for work. However, the next problem of job feasibility undertaken by the majority of youth in Indonesia is still not feasible and does not prioritize the quality and capacity of skills, still a crude force. In 2009, according to data from the ILO that $60 \%$ of the unemployment rate was youth under the age of 35 years. The unemployment rate reached $22.2 \%$ in Indonesia and $13.9 \%$ in ASEAN region.

Solutions offered is that it is necessary to change the pattern of life of fishermen. This is related to the mindset and habits. A consumptive pattern of life must be changed so that fishermen do not slump economy

6http://www.lautanquran.com/modules.php?op=modload\&name 
during a famine. In addition, get used to saving culture in order not trapped by loan sharks. In addition, it is necessary to build a verified special job eye prepared for the famine, such as processing fish into food, coastal area management with tourism and other forms of economic strengthening, so as to increase the selling price of fish, in addition to relying on raw fish. In addition, and marketing facilities. The need to support the completeness of boat technology and fishing equipment, so that the ability of Indonesian fishermen can be commensurate with other nations fishermen. Neither is the fish processing and selling facilities, so the selling price of fish can be improved.

Third, social problems among youth are quite complex. The large number of youths involved in acts of magnitude, crime, drug abuse, free sex and HIV \& AIDS transmission. Based on data from the National Narcotics Agency, in 2012 as many as 9, 5677 people were involved in drug abuse.The solution offered: One strategy to overcome these problems is the need to have programs that open up opportunities for youth to reflect and formulate transformative steps.

In addition, the need for a social policy of the government that contains programs that favor the fishermen, Government policies related to poverty reduction must be bottom up in accordance with the conditions, characteristics, and needs of fishermen community. A policy that was born based on the participation or involvement of fishing communities, but also as a subject. In addition, strengthening in terms of the zoo-related law, strengthening of marine patrol fleets, and fishing gear arrangements that do not exploit marine wealth and environmentally friendly and Improving the quality of fishing gear and marketing facilities, it needs to support the completeness of boat technology and fishing equipment so that the ability of Indonesian fishermen can be commensurate with other nation's fishermen. Neither is the fish processing and selling facilities, so the selling price of fish can be improved.

\section{Conclusion}

Optimizing the role of youth as the main pillar of maritime culture development is a preventive step for the enhancement of marine exploration. The utilization of maritime potency is one of the first and the 
next step to formulate programs of youth empowerment and creative youth creative, innovative and sustainable as one solution to solve development problems youth today. Youth must be actively involved in building inter-sectoral partnerships (civil society, private and government) to succeed in human development in Indonesia. Given Indonesia has Demographic Bonus compared to other countries, the empowerment of demographic bonus is Indonesian youth in managing marine potency very necessary and cared for.

Implementation of this program is carried out in accordance with the following technologies:

1. Improving the quality of Indonesian youth education ever since. In this case, the government can work with education providers to provide more understanding related to the utilization of marine potential.

2. The need to change the pattern of life of fishermen. This is related to the mindset and habits. Consumptive lifestyle must be changed so that fishermen do not slump their economy during a famine. In addition, it is necessary to build a verified special job eye prepared for the famine period, such as processing fish into food, etc.

3. Improved quality of fishing gear and marketing facilities. The need to support the completeness of boat technology and fishing equipment, so that the ability of Indonesian fishermen can be commensurate with other nations fishermen.

4. The need for a social policy of the government that contains programs that favor the fishermen, Government policies related to poverty reduction must be bottom up in accordance with the conditions, characteristics, and needs of fishing communities.

This program is able to be applied in a wide sphere so that preventive purposes in optimum utilization of marine potency can be achieved. The program of marine utilization especially with the empowerment of Indonesian youth from an early age if applied in the wide area make it easier for the government to overcome the problems of the State related to unemployment. The emerging indication is the occurrence of optimal quality of human resources related to the utilization of sea products so that the readiness of the State of Indonesia in utilizing the demographic 
bonus is optimally possible. This program is able to produce the quality of the nation's generation to contribute to the progress of the Indonesian nation.

\section{Bibliography}

Salim Bahreisy, Tafsir Ibnu Katsir Jilid 4, Surabaya: Bina Ilmu, 2005.

Kementerian Agama RI, Al-Qur'an dan Tafsirnya Jilid I, Jakarta: Lentera Abadi, 2010.

http://www.lautanquran.com/modules.php?op=modload\&name 